\title{
BETWEEN THE CENTER AND THE PERIPHERY: THE REgIONAL ELECTIONS AND THE PATH TO FISCAL FEDERALISM
}

\author{
Brunetta Baldi and Filippo Tronconi
}

The regional elections of 28-29 March 2010 saw the indisputable victory of the center-right, which took over the presidency of four regions that had previously been held by the center-left, but they also brought about significant changes in the power relations within the two main groupings. The Partito Democratico (PD, Democratic Party) and the Popolo della Libertà (PdL, People of Liberty) emerged from the elections noticeably weakened, while there were gains for other alliance members within the coalitions. The Lega Nord (LN, Northern League), which for the first time took over the presidency of two important regions (Piedmont and Veneto), made the greatest gains, but the results were also good for Italia dei Valori (IdV, Italy of Values), which succeeded in gaining a more or less stable vote after its excellent showing in the previous general and European elections. The Unione di Centro (UdC, Union of the Center) decided on a strategy of variable alliances with the main coalitions, enabling it to take full advantage of its pivotal position, but it will be difficult to repeat this at the national level, at least under the current electoral rules. Outside the two main groupings, the surprising showing of the MoVimento 5 Stelle (Five Star Movement), led by the satirist Beppe Grillo, is certainly worthy of attention.

All this should be seen within the context of a marked fall in voter turnout, which dropped to its lowest-ever level of 63.6 percent,

Notes for this chapter begin on page 137 . 
indicating an ever more worrying distance between the Italian people and their representative institutions. The election results reflect a largely national profile in the structure of the competition, despite the political and institutional strengthening that regional governments had seen during the past decade, thanks to an intense series of reforms. The regions have struggled to adopt an autonomous political character, and the process of federalization that is under way in the country should be seen as a transformation that is far from complete and whose outcome is still uncertain. The long-awaited fiscal federalism is taking its first steps, but there are signs that it risks being more fictitious than real.

This chapter will analyze the main themes of the electoral campaign, the structure of the political offer, and the results of the regional elections. In the final section, we will outline the main features and the current state of the process of fiscal federalism, a reform that is intended to redefine the financial relations between the center and the periphery and that has been placed at the top of the government's agenda as a result of the LN's electoral success. ${ }^{1}$

\section{The Election Campaign}

Despite their growing institutional importance, the regions and the policies pursued by their governments have rarely taken center stage in election campaigns for the renewal of their political make-up. They were not even noticeably important when the previous elections took place. This time around, though, it was fair to assume that the implementation of the 2001 reform of Title V of the Constitution, ${ }^{2}$ particularly fiscal federalism, would capture everyone's attention.

The start of the campaign was, however, unexpectedly marked by controversy regarding the presentation of the Lazio lists. On 27 February, the deadline for the formal submission of the electoral lists, the PdL representative failed to deliver the necessary documents to the court on time. This delay was apparently caused by some lastminute changes to the lists. ${ }^{3}$ This put the center-right coalition in the difficult position of having to enter the elections without the involvement of the largest party in the most highly populated province (with over 4 million inhabitants, out of a total of 5.6 million in the entire region). The two levels of judgment subsequently handed down by the Regional Administrative Tribunal and by the Council of State confirmed the initial ruling not to allow the PdL's lists, even though the government had hurriedly attempted to repair the damage by approving an urgent decree, in a matter of days, providing the "correct interpretation" of the regional electoral law. As far as the Regional Tribunal 
was concerned, however, this decree did not take into account the fact that the legislation that it referred to (Law No. 108/1968, which set out the requirements for the submission of lists in the election of regional councils) was national, but applied only to those regions that had not made their own autonomous arrangements-and the Lazio region had done so in 2005. ${ }^{4}$ This left the PdL in Rome with the sole option of shifting its votes to the personal list of the center-right presidential candidate, Renata Polverini.

The other topic that dominated much of the electoral campaign concerned news broadcasting. On 9 February, the Communications Regulatory Authority (AGCOM), which oversees radio and television services, introduced a new rule for talk shows relating to the news. This regulation was so restrictive that it was impossible to broadcast any programs with a political content during the period of the electoral campaign, thereby preventing the broadcast of popular programs such as Annozero, Ballarò, and Porta a Porta. ${ }^{5}$ With the arguments about the "lists chaos" in Lazio beginning to die down, the focus shifted to television news broadcasting, a recurring subject in all Italian electoral campaigns ever since the arrival of media magnate Silvio Berlusconi on the political scene. In all this, the legislative policies proposed by the parties and the coalitions, the profiles of the candidates, and the retrospective assessments of what had and had not been achieved by the outgoing regional councils never moved into the spotlight of political debate, nor did they reach the front pages of the daily newspapers. Consequently, these matters failed to gain the attention of the electorate.

The same point may be made about fiscal federalism, a topic that was clearly absent from the election campaign in spite of the ongoing process of reform that will redefine the organization of public finances, introducing greater autonomy and more responsibility for regional governments. The commitment made by the governing alliance between the LN, which based its own electoral program on the fiscal question, and the PdL meant that there was no opportunity to discuss the effects of fiscal federalism on the various regional entities in certain key sectors, such as health and economic development. ${ }^{6}$ This may be explained by two aspects of the reform: first, its largely unfinished and partly fictitious nature, which is far from revolutionary in its content and which failed to stimulate a debate among the regions; ${ }^{7}$ and, secondly, its capacity to cause discord, bearing in mind the existing conflicts between the North and the South of the country, on which even the parties forming the majority are divided. These conflicts are also the source of particular tension between Gianfranco Fini's Futuro e Libertà per l'Italia (FLI, Future and Freedom for Italy) 
and Umberto Bossi's LN over the more or less solidaristic shape that federalism should take. ${ }^{8}$

\section{The Political Offer}

The regional electoral campaign had an almost exclusively national flavor because the coalition strategies in use reflected the dynamics taking place in the national political arena. The building of the political offer thus had to balance the specific requirements of each local situation with the strategies and needs at the national level. From the beginning of the campaign, the regions were turned into test beds for the feasibility of alliances that could possibly be replicated at the national level. This is in spite of the fact that, unlike on previous occasions, the electoral calendar, due to the early elections in 2008, set the regional elections a considerable amount of time earlier than the normal end of the legislature, which was expected to be in $2013 .{ }^{9}$

It was the UdC, until 2008 part of the center-right coalition and after that in opposition in the national Parliament, that enjoyed the greatest room for maneuver, as far as coalition strategies were concerned. The centrist parties made good use of their pivotal position to negotiate alliances, region by region, with the two main parties. The UdC opted to support the center-right candidate in three cases (Lazio, Campania, and Calabria), while in four regions it decided to support the progressive candidate (Piedmont, Liguria, Marche, and Basilicata). In Puglia, it backed the independent candidate Adriana Poli Bortone, while it presented its own candidates in the remaining five regions (Lombardy, Veneto, Emilia-Romagna, Tuscany, and Umbria). As we shall see in the next section, it was only in Lazio and Puglia that the UdC's support could reasonably be considered decisive for the election results. On the right of the political spectrum, the alliance between the PdL and the LN, which the national government is based on, was confirmed in all the regions where the latter party had candidates, and this alliance was never extended to include the UdC.

As for the left, the coalition games were much more complicated. In three cases (Piedmont, Liguria and Basilicata), the broadest possible alliance was chosen, from the UdC to the alternative left-wing parties, with the IdV included too. But there was no agreement between the left parties in another three cases: in Marche, the Forza del Sud (FdS, Force of the South) and the Sinistra Ecologia e Libertà (SEL, Left Ecology and Freedom) presented a common candidate running against the PD candidate. In Campania and in Lombardy, the SEL remained part of the center-left coalition, while the FdS broke away, presenting 
its own candidate, Paolo Ferrero, the national secretary, in Campania. There was a rift in Calabria between the PD, which chose as its candidate the outgoing Agazio Loiero (whom the radical left also supported), and the IdV, which chose the entrepreneur, Filippo (Pippo) Callipo. These elections also saw the first appearance of Grillo's party, the Five Star Movement. ${ }^{10}$ This party presented lists and candidates in five regions. Table 4.1 shows the geographical distribution of the electoral alliances across the country.

The selection of candidates for the presidencies of the regional councils had a markedly bumpy passage in both of the main alignments. In the center-right, the most controversial situation arose in the North, where the LN hoped to obtain two candidacies in the main regions. All of the requests made by Bossi's party had been accepted, and already by the end of 2009 they had put up their own candidates in Piedmont and Veneto. In the latter case, the informal agreement was that the LN candidate, Luca Zaia, would give up his position as minister of agriculture in the national government the day after the elections, in favor of the outgoing Veneto president, Giancarlo Galan. ${ }^{11}$

In the main center-left party, there was much bad feeling as a result of the decision to support the candidacy of Emma Bonino in Lazio. This choice involved a difficult situation brought about by the resignation of the president Piero Marrazzo, who was involved in a scandal of a

TABLE 4.1 The political offer: Number of candidates for the presidency and structure of the coalitions

\begin{tabular}{lcl}
\hline Region & Candidates (total) & \multicolumn{1}{c}{ Main Electoral Alliances } \\
\hline Piedmont & 4 & FdS-SEL-IdV-PD-UdC || PdL-LN \\
Lombardy & 6 & FdS || SEL-IdV-PD || UdC || PdL-LN \\
Veneto & 7 & FdS-SEL-IdV-PD || UdC || PdL-LN \\
Liguria & 2 & FdS-SEL-IdV-PD-UdC || PdL-LN \\
Emilia-Romagna & 4 & FdS-SEL-IdV-PD || UdC || PdL-LN \\
Tuscany & 5 & FdS-SEL-IdV-PD || UdC || PdL-LN \\
Marche & 3 & FdS-SEL || IdV-PD-UdC || PdL-LN \\
Umbria & 3 & FdS-SEL-IdV-PD || UdC || PdL-LN \\
Lazio & 3 & FdS-SEL-IdV-PD || UdC-PdL \\
Campania & 4 & FdS || SEL-IdV-PD || UdC-PdL \\
Puglia & 4 & FdS-SEL-IdV-PD || UdC || PdL \\
Basilicata & 5 & FdS-SEL-IdV-PD-UdC || PdL \\
Calabria & 3 & FdS-SEL-PD || IdV || UdC-PdL \\
\hline
\end{tabular}

Source: Ministry of the Interior. 
sexual nature and who had been certain, up until a few months before the election, to stand again as a candidate. The frantic search for an authoritative candidate produced no results until, early in the new year, the Radicals decided to delay matters no further and launched the candidacy of their own historic leader. Taken by surprise, the PD eventually agreed to support a candidate who was not of their choice and who was sure to cause bitterness among the Catholic sectors of the party: for several decades, Bonino had been one of the leading figures in many campaigns pressing for a secular state, starting with the historic battles for the introduction of divorce and for the right to abortion in the 1970s.

In three cases, the selection of the center-left candidate was carried out via primary elections. In Calabria, the primaries confirmed and legitimized the predictable decision of the outgoing Loiero to stand for re-election. In Umbria, the choice of candidate was more hotly contested. The outgoing president, Maria Rita Lorenzetti, who had initially announced her intention to seek a third mandate, was forced to take a step backward. The PD's internal disagreements made it impossible to find a candidate who could enjoy the support of all members. This meant that it was the electors who would decide, and in the end they gave the victory to Catiuscia Marini, the candidate preferred by the party's national leadership. ${ }^{12}$

However, the most heated contest was in Puglia, as had been the case five years earlier. To begin with, the PD had opted for a broad alliance that would include the centrists in the UdC. There was a price to pay for this pact (seen as strategically important in light of a possible alliance at the national level): the outgoing president and secretary of SEL, Nichi Vendola, would have to stand down and not seek reelection, because he was not liked by the centrists. Vendola had no intention of being sidelined in this way, and he announced his own candidacy. The drawn-out internal battle within the center-left came to an end on 24 January, when primary elections were held, repeating the scenario that had occurred five years earlier. The battle for the candidacy was fought between Vendola and Francesco Bocca, a moderate economist supported by the PD's national leadership and, in particular, by Massimo D'Alema, himself from Puglia, who had been defeated in 2005. The result, an unexpected victory for Vendola with 67 percent of the votes, forced the PD to accept, in yet another region, a candidacy that it had opposed for many months and an outcome that made any alliance with the UdC impossible. As for the center-right, they decided not to build a broad alliance in Puglia with the centrists, led by Bortone, the ex-mayor of Lecce, who would have had a strong chance of winning. Thus, the competition took on a tri-polar form in this region 
as well, but with a more competitive center than elsewhere, and one that proved to be decisive for the outcome of the elections.

\section{The Election Results: Presidents, Parties, and Coalitions}

If compared with the results in 2005 , the 2010 regional elections unquestionably marked a success for the conservative front. The control of 11 of the 13 administrations was being contested, and, following the elections, the situation had more or less evened out, with seven regions now controlled by the center-left and six by the center-right. Four regions (Piedmont, Liguria, Lazio, and Campania) had all "changed color" in favor of the PdL and its allies. Looking beyond the purely numerical position, it is worth considering the geographical spread of the vote. The center-right by now controls virtually the whole of the North-the only exceptions being the small regions that had not been involved in these elections (Valle d'Aosta and Trentino-Alto Adige) and Liguria - and the whole of the South (where only Basilicata remained a PD stronghold). Thus, the center-left has been almost exclusively limited to running the "red zone" regions of central Italy (see table 4.2).

Of the four regions where the outcome was considered uncertain in the polls just before the election (Piedmont, Liguria, Lazio, and Campania), ${ }^{13}$ only Liguria remained center-left. In Piedmont and Lazio, the

TABLE 4.2 Results of the competition for the presidencies (party membership shown in parentheses)

\begin{tabular}{lllcll}
\hline Region & $\begin{array}{l}\text { Outgoing } \\
\text { President }\end{array}$ & Elected & $\%$ & $\begin{array}{l}\text { Second } \\
\text { Candidate }\end{array}$ & $\%$ \\
\hline Piedmont & Bresso (PD) & Cota (LN) & 47.3 & Bresso (PD) & 46.9 \\
Lombardy & Formigoni (PdL) & Formigoni (PdL) & 56.1 & Penati (PD) & 33.3 \\
Veneto & Galan (PdL) & Zaia (LN) & 60.2 & Bortolussi (PD) & 29.1 \\
Liguria & Burlando (PD) & Burlando (PD) & 52.1 & Biasotti (PdL) & 47.8 \\
Emilia-Romagna & Errani (PD) & Errani (PD) & 52.1 & Bernini (PdL) & 36.7 \\
Tuscany & Martini (PD) & Rossi (PD) & 59.7 & Faenzi (PdL) & 34.4 \\
Marche & Spacca (PD) & Spacca (PD) & 53.2 & Marinelli (PdL) & 39.7 \\
Umbria & Lorenzetti (PD) & Marini (PD) & 57.2 & Modena (PdL) & 37.7 \\
Lazio & Montino* (PD) & Polverini (PdL) & 51.1 & Bonino (Radicali) & 48.3 \\
Campania & Bassolino (PD) & Caldoro (PdL) & 54.2 & De Luca (PD) & 43.0 \\
Puglia & Vendola (SEL) & Vendola (SEL) & 48.7 & Palese (PdL) & 42.3 \\
Basilicata & De Filippo (PD) & De Filippo (PD) & 60.8 & Pagliuca (PdL) & 27.9 \\
Calabria & Loiero (PD) & Scopelliti (PdL) & 57.8 & Loiero (PD) & 32.2 \\
\hline
\end{tabular}

*Ad interim (replaces Piero Marrazzo, who resigned on 27 October 2009).

Source: Ministry of the Interior. 
victory went to the center-right, although with a very small majority (0.4 percent and 2.8 percent, respectively), while in Campania the PdL candidate was elected by a margin of over 10 percent. Particular attention should be given to the victory in Lazio, given the peculiar conditions in which the electoral campaign was conducted and the coverage it had received in the media. The center-right's gamble turned out to be successful, as moderate votes were shifted toward the Polverini list, which obtained 34.5 percent in the province of Rome and 26.3 percent in the region overall.

The other contest that had aroused great interest during the electoral campaign - the one in Puglia - was won by the center-left. The outgoing president, Vendola, was re-elected with an excellent personal performance: 48.7 percent of the votes were obtained by the president, almost 3 percent more than the sum of the votes for the parties that supported him, even taking into account the fact that he was helped by his opponents' inability to form a common front. The total number of votes gained by the two center-right candidates, Rocco Palese (42.3 percent) and Bortone (8.7 percent), would have sufficed, in fact, to beat the left-wing candidate-provided, of course, that there had been full compatibility between the two sets of voters.

The outcome of the campaigns for the regional presidencies that we have examined thus far is only one of the two levels on which the contest took place. As far as the proportional aspect is concerned, the votes go to the competing lists for the election of councils (see table 4.3). ${ }^{14}$ Although four regions had been snatched from the opposing group, the results for the major party in the center-right group can certainly not be considered positive. On the contrary, it was the PdL's worst result since the 2005 elections, with a considerable drop, compared to both the 2008 general elections (-7 percent) and the European elections the following year (-5.5 percent). Within the alliance itself, however, the LN has every right to claim to be the real winner of this election. Not only were two of its members sitting for the first time at the head of influential regions (Piedmont and Veneto), but the party achieved its best-ever result, beating its already positive showing in the 2008 and 2009 elections. Thus, the LN is actually the largest party in Veneto, and for the first time it has become a relevant force in the "red regions" of central Italy. The LN's result in Emilia-Romagna, traditionally a stronghold for the left, was particularly striking, with an amazing 13.7 percent. This created the need for a new equilibrium within the center-right coalition. While in 2008 there were 3.9 PdL voters for every League voter, the figure had fallen to 2.2 in 2010. If we consider the three big regions in the North alone, the two parties are practically on a par: for every League voter there are 1.1 voters for the PdL. 
TABLE 4.3 Results for the main parties in the proportional contest (percentages)

\begin{tabular}{lcccccccccc}
\hline Region & & & & & & & & & $\begin{array}{c}\text { Pres. } \\
\text { list }\end{array}$ & $\begin{array}{c}\text { Pres. } \\
\text { list } \\
\text { (right) }\end{array}$ \\
\hline Piedmont & 2.6 & 1.4 & 6.9 & 23.2 & 3.9 & 25.0 & 16.7 & 3.7 & 3.2 & \\
Lombardy & 2.0 & 1.4 & 6.3 & 22.9 & 3.8 & 31.8 & 26.2 & 2.3 & & \\
Veneto & 1.6 & 1.2 & 5.3 & 20.3 & 4.9 & 24.7 & 35.2 & 2.6 & & \\
Liguria & 3.9 & 2.5 & 8.4 & 28.3 & 3.9 & 29.3 & 10.2 & & 3.7 & 6.1 \\
Emilia-Romagna & 2.8 & 1.8 & 6.4 & 40.6 & 3.6 & 24.6 & 13.7 & 6.0 & & \\
Tuscany & 5.3 & 3.8 & 9.4 & 42.2 & 4.8 & 27.1 & 6.5 & & & \\
Marche & 3.9 & 2.6 & 9.1 & 31.1 & 5.8 & 31.2 & 6.3 & & & \\
Umbria & 6.7 & 3.4 & 8.3 & 36.2 & 4.4 & 32.4 & 4.3 & & & \\
Lazio & 2.7 & 3.1 & 8.6 & 26.3 & 6.1 & 11.91 & & & & 26.3 \\
Campania & 1.6 & 3.5 & 6.7 & 22.1 & 9.4 & 31.7 & & 1.3 & & \\
Puglia & 3.3 & 9.7 & 6.5 & 20.8 & 6.5 & 31.1 & & & 5.5 & \\
Basilicata & 2.2 & 4.0 & 9.9 & 27.1 & 7.4 & 19.4 & & & & 4.3 \\
Calabria & 4.0 & 3.8 & 5.4 & 15.8 & 9.4 & 26.4 & & & 7.0 & 9.9 \\
Italy-13 & 2.7 & 3.0 & 7.0 & 26.2 & 5.6 & $29.7^{2}$ & 12.3 & 1.8 & & \\
\hline
\end{tabular}

${ }^{1}$ The PdL did not run in the elections in the province of Rome.

${ }^{2}$ Includes votes for the Polverini list in Lazio.

Source: Ministry of the Interior.

The cause of the negative results for the PdL cannot, however, be attributed only to competition from the LN. In the southern regions, in fact, where the League did not put up any candidates, things went even worse. In Campania, Puglia, and Basilicata, the percentage drop in votes gained reached double figures, both compared with 2008 and 2009 (see table 4.4), and the deficit remains, even if the votes for the "president's lists," which we will consider later in this section, are added to those of the PdL.

Not even a general reference to the "second-rate" elections, and thus the tendency on the part of the electorate to punish the parties forming the current national government, seems to provide a sufficient explanation. The LN, as we have seen, certainly avoided negative consequences in this sense. The most convincing explanation can instead be found in the PdL's systematic difficulty in mobilizing its own voters in elections with a decidedly territorial character, especially in those parts of the country where consensus is more volatile, as has traditionally been the case in the southern regions. A similar phenomenon was in evidence in the case of the PdL's predecessor, Forza Italia, as early as the 2005 elections, again in the face of a stable result for the LN, and in the preceding ones. ${ }^{15}$ 


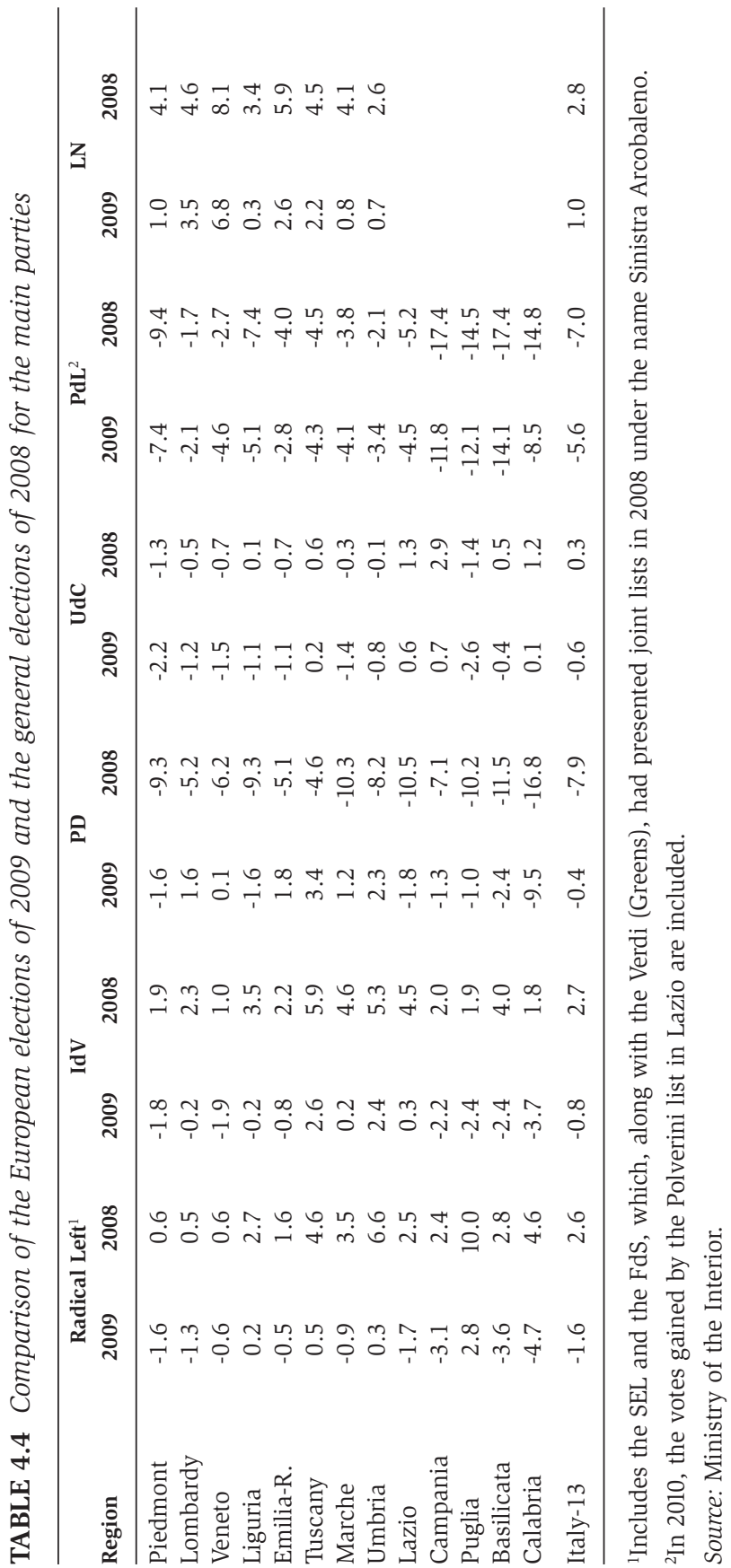


In the center-left, the picture is slightly different. The PD's results were in line with those obtained in the European elections of the previous year (26.2 percent compared to 26.6 percent in 2009), but decidedly worse than in 2008, when the newly formed party had reached 34.1 percent in its first electoral showing. In this case, the national figure hides more modest regional variations compared to 2009, apart from Calabria, where the fall in votes of 9.6 percent was largely compensated for by the excellent performance of Loiero's personal list. As for the coalition partners, Antonio Di Pietro's IdV party confirmed its state of good health (7 percent compared with 7.8 percent in 2009), at least when compared to the 2004-2006 election cycle, when it obtained around, or even less than, 2 percent. The same cannot be said for the left-wing parties, the FdS and the SEL (2.7 percent and 3 percent, respectively), which, in spite of a small recovery compared to 2008, still remained some ways off from the percentages obtained in previous years.

The UdC's results, looking beyond the fact that Pier Ferdinando Casini's party was in line with the outcome in the two preceding years, should be judged in light of its strategy for these 2010 elections, which was to exploit its position within the political spectrum by means of an extremely flexible approach to forming alliances, negotiated region by region. With the exception of Puglia, where the initial orientation for an alliance with the center-left was put in doubt by the result of the primaries, the UdC fielded its own candidates only in those regions where support for one of the two major coalitions was likely to have very little influence on the result, that is, Lombardy and Veneto, which favored the center-right, and Emilia-Romagna, Tuscany, and Umbria, which favored the center-left. In the other regions involved in the election, the choice of coalition always turned out to be decisive, with the exception of Piedmont, where, in any case, the gap between the two blocs was slight. From this point of view, the strategic decisions of the UdC can be seen as sound. With 5.6 percent of the vote, this party managed to become part of the regional government in 6 out of the 13 regions where elections were held. This result is even more impressive when we bear in mind that, in purely numerical terms, the UdC's contribution was decisive only in the cases of Puglia and Lazio. ${ }^{16}$ It remains to be seen to what extent this "third pole" strategy of the UdC can be applied at the national level, if we view the strategic decisions made at these regional elections as an indication of what might happen at the next general elections. Much will depend on any changes that are made to the electoral law, which, with the current system of majority voting, gives an opportunity for the third pole to become a decisive force solely in the Senate. ${ }^{17}$ 
Grillo's Five Star Movement achieved an unexpected success at its first appearance in an election. In Piedmont, it received 3.7 percent of the vote, probably causing the defeat of Mercedes Bresso, while in Emilia-Romagna it obtained a very high 6 percent. This can be explained, at least in part, by the scandals that had led to the resignation of the mayor of Bologna, Flavio Delbono, just a few days before the elections took place. In Bologna itself, Grillo's movement polled an amazing 8.1 percent. It will take more elections to determine whether this was a "one-off" phenomenon or whether a clever use of digital forms of communication may actually be opening up new possibilities for "virtual" political movements that can exist without territorial structures comparable to those of traditional parties.

Finally, compared with the 2005 regional elections, the 2010 results show a stronger vote for the local and regional lists (see table 4.5), that is, those lists that have a closer link between the political offer and the territory. This heterogeneous reality is demonstrated by the presence of (1) the lists of presidents (e.g., Together with Bresso, Puglia for Vendola, and I Stay in Calabria with Callipo), a phenomenon that reflects the personalization of electoral competition driven by legislative reforms, particularly by constitutional Law No. 1/1999, which introduced the direct election of presidents; ${ }^{18}$ (2) the civic lists, which reflect local demands or identities (e.g., movements such as "No Nuclear," "No TAV," "Unleague Calabria," and "Free Campania"); and (3) the regional lists, which pursue a policy of autonomy for the territory in which they compete (e.g., the MpA, Noi Sud, Veneti Indipensa). The lists of presidents have grown, both numerically (from 9 to 13) and in terms of electoral consensus. Although the national figure for 2010 may be explained in the anomalous case of Polverini's list-which, as we have seen, picked up the PdL votes in Lazio as well, following the party's failure to present candidates in the province of Rome list-it cannot be denied that the phenomenon of diversity grew significantly in the southern regions, particularly in Calabria and Basilicata. The same can be said for the civic and autonomist lists, which also grew in these latest elections, showing a mainly southern phenomenon, apart from the unusual case of Piedmont. ${ }^{19}$

As reflected in table 4.5 , the LN deserves to be considered separately, since it falls firmly within the category of regionalist parties, even though it is part of the national government. Aside from its clear victory in the northern regions (Piedmont, Lombardy, Veneto, but also Liguria), where it more or less doubled its vote, the LN has also become a significant reality in the regions of the Center, with a surprising showing in Emilia-Romagna and in Tuscany. The map of votes for the local and regional lists therefore sees the dominance-and in 
TABLE 4.5 Votes for local and regional lists: Presidents, civic/autonomist, and the LN, 2005 compared to 2010 (percentages)

\begin{tabular}{lcccccccc}
\hline & $\begin{array}{c}\text { Pres. } \\
\text { Lists } \\
\text { Region }\end{array}$ & $\begin{array}{c}\text { Civic/ } \\
\text { Auton. } \\
\mathbf{2 0 0 5}\end{array}$ & $\begin{array}{c}\text { LN } \\
\mathbf{2 0 0 5}\end{array}$ & $\begin{array}{c}\text { Total } \\
\mathbf{2 0 0 5}\end{array}$ & $\begin{array}{c}\text { Pres. } \\
\text { Lists } \\
\mathbf{2 0 1 0}\end{array}$ & $\begin{array}{c}\text { Civic/ } \\
\text { Auton. } \\
\mathbf{2 0 1 0}\end{array}$ & $\begin{array}{c}\text { LN } \\
\mathbf{2 0 1 0}\end{array}$ & $\begin{array}{c}\text { Total } \\
\mathbf{2 0 1 0}\end{array}$ \\
\hline Piedmont & 2.9 & 1.5 & 8.5 & 12.9 & 3.2 & 8.7 & 16.7 & 28.6 \\
Lombardy & - & 1.1 & 15.8 & 16.9 & - & - & 26.2 & 26.2 \\
Veneto & 4.6 & 7.3 & 14.7 & 26.6 & - & 3.0 & 35.2 & 38.2 \\
Liguria & 13.1 & 1.4 & 4.7 & 19.2 & 9.7 & 1.5 & 10.2 & 21.4 \\
Emilia-R & - & - & 4.8 & 4.8 & - & - & 13.7 & 13.7 \\
Tuscany & - & 1.3 & 1.3 & 2.6 & - & - & 6.5 & 6.5 \\
Umbria & - & - & - & - & - & - & 4.3 & 4.3 \\
Marche & - & 0.7 & 0.9 & 1.6 & 1.3 & - & 6.3 & 7.6 \\
Lazio & 13.7 & 1.9 & - & 15.6 & 27.9 & 1.5 & - & 29.4 \\
Campania & - & 1.5 & - & 1.5 & - & 14.5 & - & 14.5 \\
Puglia & 11.7 & - & - & 11.7 & 10.3 & 10.0 & - & 20.3 \\
Basilicata & - & 0.3 & - & 0.3 & 8.0 & 4.7 & - & 12.7 \\
Calabria & 2.5 & 7.6 & - & 10.1 & 18.9 & 12.5 & - & 31.4 \\
Italy-13 & 3.8 & 1.4 & 5.6 & 10.8 & 5.6 & 3.5 & 12.3 & 21.4 \\
\hline
\end{tabular}

Source: Ministry of the Interior.

many cases, the absolute supremacy-of the LN, as far as the CenterNorth is concerned. There are also clear signs of new ferment in the South, where the League did not run but where lists appeared, alongside the lists of presidents, that were of an identitarian or autonomist nature, or else were linked to single individuals, based on an exclusively local consensus.

\section{Regions and Fiscal Federalism}

The return of the LN to the national government, following the general elections of 2008, gave further momentum to federalist reforms, particularly fiscal federalism, for which Decree Law No. 42 was passed in 2009. The complex underlying problem that this measure tackled, and which creates tensions within the country and between the parties forming the majority, can be seen as twofold. First, it highlights the contrast between the regions of the Center-North and those of the South in terms of internal revenue, with the former contributing twice as much to the Treasury as the latter. ${ }^{20}$ There is also a contrast between efficient and inefficient regions in terms of public spending, above all on health. The consequence is that only 7 out of 20 regions 
generate more resources through taxation than are spent on services, and all of these are concentrated in the Center-North. ${ }^{21}$ This ranges from a difference in Lombardy of income and expenditure of $+5,235$ euros per capita to Calabria, whose fiscal deficit is a massive $-3,118$ euros per capita. ${ }^{22}$ However, attention should also be drawn to the negative expenditure profile of some regions in the North. ${ }^{23}$

This was the general context in which the decree law was introduced. Above all, it aimed to restore efficiency in public expenditure through the introduction of standard costs as a new criterion for the financing of regional needs. This criterion replaced the previous one, which financed regions' needs at the level set in previous years without taking into account the efficiency of the regional administrations. This resulted in the paradoxical position whereby the more inefficient the spending, the higher the level of finances provided. With the reform, the integral expenditure will be covered, also via equalization transfers paid for by the state, on the basis of the standard cost, considered a "fair" price for services, ${ }^{24}$ which will be calculated by using as a benchmark the average of costs incurred by the most efficient regions. The decree law on fiscal federalism also extends the financial autonomy of the regions, based on the internal revenue of their territory through the forecast of (limited) taxes of their own and a share of state taxes. ${ }^{25}$ This would represent the most significant item in regional budgets, and equalization funds would be added to this, at various levels for each case, to even out the different fiscal capacities of the regions and to ensure the provision of essential services. ${ }^{26}$

The clear victory of the LN in the 2010 regional elections-but perhaps also the fear of an early end to the legislature-led to a speeding up of the implementation of the decree law on fiscal federalism, a promise that is, as already mentioned, at the heart of the PdL-LN alliance. The first law to be implemented, Decree Law No. 85/2010, was enacted rapidly, obtaining support from the IdV, abstention from the $\mathrm{PD}$, and opposition only from the UdC and the Alleanza per l'Italia (ApI, Alliance for Italy). This law concerns the so-called state-owned properties federalism (federalismo demaniale), which provides for the attribution of public assets to regions and local governments in order to guarantee them resources that can generate income. But the parliamentary passage of fiscal federalism, as emphasized in the report delivered in Parliament on 30 June by Giulio Tremonti, the minister of economy and finance, is still some way from completion, and there are many issues to be resolved. First of all, the concrete definition of the standard costs that will make it possible to distinguish between the efficient regional administrations and the inefficient ones has yet to be established. Secondly, the equalization funds have to be streamlined 
in order to ensure, on the one hand, the overall financing required to provide essential services (yet to be defined) in the key sectors of health, welfare, and education and, on the other, a reduction of the gap with regard to the fiscal capacity of the regions.

This is a complex reform around which consensus is still uncertain, and the camp of the regions risks becoming divided internally, given the greater difficulties of the southern regions. In this context, the Conference of Regions, led by the re-elected Vasco Errani, the president of Emilia-Romagna, had insistently asked the government for a more systematic exchange of views and a greater say in decisionmaking. However, relations between the regions and Tremonti are strained because of the economic-financial maneuver launched at the end of May 2010, which imposed deep cuts on regional expenditure and on the transfer of central funds. ${ }^{27}$ The government's promise to review the position of the regions with a maxi-amendment on 15 July, which would allow some "discounts" on the anticipated cuts, met with firm opposition from Tremonti and was not kept. As a result, the presidents of the regions began a hard standoff with the central government, going so far as to threaten to give back their "delegated powers," without, however, achieving any results. ${ }^{28}$

The tension re-emerged following the launch of the draft version of the new decree, which was to implement, more or less in its entirety, the decree law on fiscal federalism. ${ }^{29}$ This weighty measure, granted preliminary approval by the Council of Ministers on 6 October 2010, is intended to tackle the issue of standard costs in the health sector and to outline the new regional financial autonomy. Again, the Conference of Regions raised a procedural question regarding this measure, pointing to the lack of involvement of the regional governments. ${ }^{30}$ Looking beyond the conflict caused by Minister Tremonti's budget, which the regions unanimously continue to describe as unworkable, ${ }^{31}$ it seems impossible to argue against the idea that the method pursued by the government has little that is federal about it. A federalism that is imposed from above, a long way from the territories-one that neither invites any input from the regions nor negotiates with the autonomous bodies-is, at the very least, lacking in credibility.

The doubts concern both the method and the contents of the measure. The new regional finance system does not differ very much from the present arrangements: the regional tax revenues remain the same (IRAP, additional IRPEF, share of value-added tax), with a slight increase in maneuverability (especially on the additional IRPEF), but one that is limited by the aim not to increase fiscal pressure. In addition, as far as the specific definition of standard costs in the health sector is concerned, the mechanisms set out do not seem very different 
from those currently operating. ${ }^{32}$ Given this overall picture, with little that is new and much that is disappointing, when considering the expectations that had been raised, it is hard to understand how the regions are going to be able to resolve both their immediate and their more general financial difficulties. ${ }^{33}$

The resumption of the path toward federalism does not, however, appear to be confined to the fiscal issue. In conjunction with the celebrations that have begun for the 150th anniversary of Italian unification, the LN has clearly expressed the position that federalism could be achieved even at a strictly institutional level, with particular reference to the birth of a federal Senate and the devolution of new powers. ${ }^{34}$ These declarations, made after the regional vote, may not actually lead to any implementation, due to the government crisis that began in the autumn of 2010. However, they do give rise to a more fundamental question: does this long and uncertain path toward federalism in Italy represent a response to a demand for autonomy coming from the territories, or does it stem only from the position of strength that the LN has gained in the Italian political system? In other words, who really wants federalism? The risk that may be emerging is that of a fictitious federalism, destined to be played out on a rhetorical level and in proclamations made by the LN, rather than having any real substance.

In any case, the regions still have not come forward as leading players in the federal process in Italy, a process that they seem to be subjected to rather than leading. The reform of Title $\mathrm{V}$ of the Constitution (Constitutional Law No. 3/2001), the most federalist of those approved to date, has remained a commitment on paper, ${ }^{35}$ and the new reform on fiscal federalism, as well as being "imposed from above," appears to be lacking in truly innovative content, if we disregard the possible improvements of efficiency in public expenditure, an intervention that any decentralized state can operate without making it a federal one.

- Translated by David Bull

\section{Notes}

1. Although this chapter was jointly produced, the first, second, and third sections that follow are to be attributed to Filippo Tronconi and the fourth section to Brunetta Baldi.

2. The 2001 reform of Title $V$ of the Constitution restructured the relationships between the state, the regions, and the local authorities, launching a federalist process that attributes administrative and legislative competencies to the 
regions and local authorities-a provision that involves financial autonomy as well, although little progress has been made on this thorny issue.

3. See A. Frenda, "Regionali, liste chiuse. Pdl in ritardo a Roma: Possibile esclusione," Corriere della Sera, 28 February 2010, 17.

4. Regional Law, No. 2, Art. 8, 13 January 2005. See E. Menicucci, “Decreto inapplicabile’ No del Tar alla lista Pdl,” Corriere della Sera, 9 March 2010, 2.

5. AGCOM initially extended the application of this ruling to private networks, but a later sentence from the Regional Tribunal (12 March) limited its validity to public service broadcasters. See P. Conti, “'Talk show in onda’: Il Tar annulla lo stop alle private," Corriere della Sera, 13 March 2010, 8. The paradoxical result of this decision was that while the electoral campaign was effectively banned on the public channels, it could still go ahead on the private networks, which more or less meant the networks owned by the prime minister.

6. L. Tentoni, "Elezioni regionali: Il grande assente e' il federalismo fiscale. Il significato perso del voto," Finanza in Chiaro.it, 9 March 2010, http://www. finanzainchiaro.it/dblog/articolo.asp?articolo $=7651$.

7. For further information on the reform, see the section in this chapter titled "Reform and Fiscal Federalism."

8. A. Panebianco, "Destra moderna o Lega Sud?” Corriere della Sera, 7 September 2010.

9. The split between Fini and Berlusconi, which would lead to the birth of the FLI and to the government crisis, thus increasing the likelihood of early elections, did not begin to take clear shape until after the regional elections.

10. A famous comedian, Grillo is also one of the most popular bloggers on the Internet and is well-known for his grassroots campaigns to clean up politics.

11. This actually took place on 16 April 2010. On the candidacy of Zaia, see M. Cremonesi, "Veneto, Bossi prepara la 'volata' di Zaia," Corriere della Sera, 18 December 2009; M. Cremonesi, "Pdl, pace in Veneto: Galan sarà ministro," Corriere della Sera, 23 December 2009.

12. F. Marangoni, "Umbria: La stabilità degli equilibri e dei rapporti di forza," in Le elezioni regionali del 2010, ed. B. Baldi and F. Tronconi (Bologna: Istituto Carlo Cattaneo, 2010), 153-164.

13. According to the Italian legislation, the latest polls can be published two weeks before the vote. See R. Mannheimer, "Incertezza in quattro regioni: Lazio, Piemonte, Liguria e Campania. Centrodestra stabile, PD in ripresa. L'astensione potrebbe crescere," Corriere della Sera, 13 March 2010, 2-3.

14. The Tatarella law approved in 1995, with the amendments introduced by the constitutional Law No. 1/1999, establishes a system of two votes on one single voting slip. On the left-hand side, there is a choice of candidates for the presidency in a majority contest on a regional basis, while on the right-hand side there is a choice of party symbols in a proportional contest on the basis of provincial districts. The list (or coalition of lists) linked to the elected president receives a majority premium that ensures the necessary number of seats for the executive to govern. Among the regions voting in 2010, seven (Tuscany, Marche, Umbria, Lazio, Campania, Puglia, and Calabria) approved amendments that were more or less significant in the electoral legislation. However, none of them modified the "core" of the electoral system, that is, its mixed nature and the logic of the majority premium. On the other hand, significant amendments were introduced to the entity of the premium (in Campania, Umbria, and Toscana), to the minimum thresholds (in Calabria, Puglia, and 
Toscana), to the system of preferences (changed in Campania, eliminated in Tuscany), and to other aspects regarding representation by gender and by territory. For further information, see the relevant chapters in B. Baldi and F. Tronconi, eds., Le elezioni regionali del 2010: Politica nazionale, territorio e specificità locale (Bologna: Istituto Carlo Cattaneo, 2010).

15. F. Tronconi and F. Marangoni, Elezioni regionali 2010: Le tendenze di lungo periodo (1996-2010), report published by the Istituto Carlo Cattaneo, 31 March 2010, http://www.cattaneo.org.

16. This is figured by subtracting the percentage obtained by the centrists from the difference between the votes for the two major coalitions. Obviously, this gives only a rough indication, as it does not take into account the "split vote," that is, the possibility that the electorate might vote for a party in the proportional section and for a candidate in the majority section who is not supported by that party.

17. On this point and on the medium-term strategies of the UdC and of the other centrist parties, see the chapter by Carlo Baccetti in this volume.

18. The personalization of the presidential contest does not necessarily advance at the same speed as the territorialization of the regional vote. It depends on whether the candidates for the presidency are representatives of the territory or whether they have been brought into the regional political offer by developments at the national level. This is the case with regard to the candidacies of Bonino and, partly, Polverini for Lazio, and the candidacy of Magdi Cristiano Allam for Basilicata. In the other regions, the lists of presidents were drawn up in support of local candidates.

19. In Piedmont, there were no fewer than 14 lists, including civic and autonomist ones, which is equivalent to one-third of the total number on a national scale.

20. The different fiscal capacity of these two regions can be explained by the wellknown gap in the levels of development, as is clearly shown by the data on the pro capita GDP (Eurostat). See the report of the Centro Studi Sintesi, Lo scarso equilibrio fiscale in Italia, 29 July 2009, http://www.centrostudisintesi. $\mathrm{com} / ? \mathrm{p}=427$.

21. G. Trovati, "Federalismo, solo sette regioni 'autosufficienti,'” Il Sole 24 Ore, 4 August 2008.

22. Data from the Centro Studi Sintesi, available online and published in LiberoMercato, 26 July 2008.

23. Along with the southern regions, Lazio and Veneto are running a deficit in the health sector. See R. Turno, "In corsia il deficit continua a salire," Il Sole 24 Ore, 22 March 2010. The high levels of expenditure in Valle d'Aosta and Trentino-Alto Adige should also be mentioned. As in the southern regions, this situation leads to a huge fiscal deficit (i.e., the difference between income and expenditure). Cf. P. Falasca and C. Lottieri, Come il federalismo fiscale può salvare il Mezzogiorno (Soveria Mannelli: Rubbettino, 2008).

24. G. Viesti, "Il federalismo difficile," Il Mulino 60, no. 5 (2010): 730-738.

25. In the decree law, the space given to the taxes raised autonomously by the regions is very limited, while there is more mention of "derivative" taxes, introduced by a state law and handed over to the regions, along the lines of the current IRAP.

26. The reform also allows for special financial measures to help the southern regions by supporting development policies that aim to reduce, in the long term, the gap between the fiscal capacity of these regions compared to the others. 
27. Decree Law No. 78, approved on 31 May 2010, established "urgent measures aimed at financial stability and economic competitiveness."

28. This refers mainly to the administrative powers transferred to the regions making use of the "devolved power" as set out in the old version of Article 118 of the Constitution. See R. Turno, "Passa il rigore, le regioni rompono," Il Sole 24 Ore, 10 July 2010.

29. E. Bruno and M. Mobili, "Fisco regionale verso il via: Cinque condizioni dai governatori," Il Sole 24 Ore, 6 October 2010. Also see "Federalismo: Muro contro muro Governo-Regioni, è stallo," 24 November 2010, on the Web site of the Conference of the Regions, http://www.regioni.it.

30. See communiqués of the Conference of the Regions, dated 6 and 28 October 2010, http://www.regioni.it.

31. See, for example, the communiqué of the Conference of the Regions, dated 22 July 2010, http://www.regioni.it

32. M. Bordignon, "L'eccesso di velocità può far male al federalismo," Il Sole 24 Ore, 7 October 2010. Also see the contributions posted on http://www.lavoce. info: M. Bordignon and N. Dirindin, "Costi standard: Nome nuovo per vecchi metodi," 29 September 2010; V. Mapelli, "Se il costo standard diventa inutile," 8 October 2010; A. Zanardi, "Il nuovo fisco regionale? Quello di prima," 12 October 2010.

33. G. Trovati, "Federalismo alla prova finale," Il Sole 24 Ore, 29 November 2010. However, at the end of the year, an agreement was being drawn up between the regions and the national government to build a consensus on the introduction of fiscal federalism in exchange for a partial review of the cuts in central funding. See, for example, "Regioni e governo siglano l'intesa sul federalismo fiscale: Premi a chi rispetta il patto di stabilità," Il Sole 24 Ore, 16 December 2010.

34. Interview with Roberto Calderoli, the minister of legislative simplification and a leading member of the League, published by Il Sole 24 Ore, 4 April 2010.

35. T. Groppi, "Il titolo V cinque anni dopo, ovvero la Costituzione di carta," Le Regioni, no. 3-4 (2007): 421-433. 